\title{
Efficiency of stormwater control measures for combined sewer retrofitting under varying rain conditions: Quantifying the Three Points Approach (3PA)
}

Sørup, Hjalte Jomo Danielsen; Lerer, Sara Maria; Arnbjerg-Nielsen, Karsten; Mikkelsen, Peter Steen; Rygaard, Martin

\section{Published in:}

Environmental Science \& Policy

Link to article, DOI:

10.1016/j.envsci.2016.05.010

Publication date:

2016

Document Version

Peer reviewed version

Link back to DTU Orbit

Citation (APA):

Sørup, H. J. D., Lerer, S. M., Arnbjerg-Nielsen, K., Mikkelsen, P. S., \& Rygaard, M. (2016). Efficiency of stormwater control measures for combined sewer retrofitting under varying rain conditions: Quantifying the Three Points Approach (3PA). Environmental Science \& Policy, 63, 19-26.

https://doi.org/10.1016/j.envsci.2016.05.010

\section{General rights}

Copyright and moral rights for the publications made accessible in the public portal are retained by the authors and/or other copyright owners and it is a condition of accessing publications that users recognise and abide by the legal requirements associated with these rights.

- Users may download and print one copy of any publication from the public portal for the purpose of private study or research.

- You may not further distribute the material or use it for any profit-making activity or commercial gain

- You may freely distribute the URL identifying the publication in the public portal 
1 Efficiency of stormwater control measures for combined sewer 2 retrofitting under varying rain conditions: Quantifying the Three

3 Points Approach (3PA)

4 Hjalte Jomo Danielsen Sørup ${ }^{1,2} *$, Sara Maria Lerer ${ }^{1}$, Karsten Arnbjerg5 Nielsen $^{1,2}$, Peter Steen Mikkelsen ${ }^{1,3}$ and Martin Rygaard ${ }^{1,3}$

$6 \quad{ }^{1}$ Urban Water Systems Section, Department of Environmental Engineering, Technical

7 University of Denmark, Bygningstorvet Building 115, 2800 Lyngby. Denmark.

$8{ }^{2}$ GDSI, Global Decision Support Initiative, Technical University of Denmark,

9 Produktionstorvet, Building 424, 2800 Lyngby, Denmark

$10{ }^{3}$ Water DTU, Center for Water Activities at DTU, Technical University of Denmark, 11 Bygningstorvet Building 115, 2800 Lyngby. Denmark.

$12 *$ Corresponding author. Email: hjds@env.dtu.dk

13

16 Acknowledgements

17 This research was funded partly by The Foundation for Development of Technology in

18 the Danish Water Sector (project number 7255-2011) and partly by the Danish Council

19 for Independent Research as part of the project "Reducing Uncertainty of Future

20 Extreme Precipitation” (contract no. 09-067455). We would like to thank our project

21 partners the utility companies HOFOR and Aarhus Water. 
22 Efficiency of stormwater control measures for combined sewer retrofitting under

23 varying rain conditions: Quantifying the Three Points Approach (3PA)

\section{Introduction}

40 Management of urban stormwater, i.e. rainwater that runs off paved urban areas, is

41 complex because of conflicting needs and objectives. Traditional stormwater

We present a method to assess and communicate the efficiency of stormwater control measures for retrofitting existing urban areas. The tool extends the Three Points Approach to quantitatively distinguish three rainfall domains: (A) rainwater resource utilisation, (B) urban stormwater drainage pipe design, and (C) pluvial flood mitigation. Methods for calculating efficiencies are defined recognizing that rainfall is both a valuable resource and a potential problem. Efficiencies are quantified in relation to rainfall volume, supplied potable water volume and volume of wastewater treated. A case study from Denmark is used to illustrate how the efficiency varies between the rainfall domains. The method provides a means for communicating some important quantitative aspects of stormwater control measures among engineers, planners and decision makers working with management of water resources, stormwater drainage and flood risks.

Keywords: stormwater control measures; stormwater management; three points approach management technology in the form of sewers is installed with the aim of draining stormwater efficiently to protect human health and human assets, but this practice often disturbs the natural water cycle and has a multitude of other detrimental environmental impacts (Schuster et al., 2005). Alternative stormwater management has gained increased attention in recent years due to different drivers such as aging infrastructure, a 
47 wish for more cyclical rather than linear systems (Chocat et al., 2007), and increases in

48 size and occurrence of extreme rainfall due to anthropogenic climatic changes

49 (Arnbjerg-Nielsen et al., 2013). A suite of newer structural and non-structural practices for stormwater management has emerged, reflecting the different perspectives involved

51 and the needs for driving the stormwater profession in new directions. These are in the

52 following called stormwater control measures (SCMs) and represent technologies such

53 as stormwater best management practices (BMPs), green infrastructure (GI), low impact

54 development (LID), sustainable urban drainage systems/sustainable drainage systems

55 (SUDS/SuDs), and water sensitive urban design (WSUD) (Fletcher et al., 2015). We

56 use SCMs in this article to refer to any combinations of practices, structures, or

57 implemented technologies that seek to reduce the negative environmental impacts of

58 sewer based stormwater systems. This is in line with the definition given by the

59 Committee on Reducing Stormwater Discharge Contributions to Pollution (2009).

60 SCMs have a multitude of expected impacts and a range of indicators can be used to

61 quantify these (Lerer et al., 2015). In the case of SCMs for stormwater harvesting there

62 is often a conflict between the aim to reduce the impact on the natural water cycle and

63 the aim to substitute drinking water. A related challenge exists in balancing the aim to

64 manage large quantities over time, i.e. from an annual water balance perspective, and

65 the aim to manage extreme rainfall, i.e. from a single event's perspective. Therefore,

66 there is a need to better distinguish between the different functions SCMs may have

67 when quantifying and reporting their efficiency, as the following examples will show.

68 Efficiency of an SCM expressed as a fraction of the total rainwater volume over

69 extended periods of time, e.g. a year, can be misleading if used in a flooding context.

70 For example, stating that an SCM controlling $60 \%$ or even $99 \%$ of the annual rainwater

71 volume will reduce the risk of urban flooding (see e.g. Armson et al., 2013 for an 
example) may be misleading as the remaining $1 \%$ of the rainwater volume is composed

73 of the extreme events with heavy peaks that exceed the design criteria for the SCM in

74 question and cause floods. Stovin et al. (2013) used a lumped sewer model to show that

75 the annual number of Combined Sewer Overflows (CSOs) can be reduced using

76 “aggressive implementation of SuDS”. The analysis considered catchments with very

77 frequent CSOs (29-59 per year) and the rainfall events analysed had return periods of

78 only two and four years. More extreme rainfall events are discussed in the study but no

79 clear conclusions are provided. Locatelli et al. (2014) and Yang et al. (2015) both

80 modelled and experimented with green roofs. Locatelli et al. (2014) validated a model

81 for three different green roofs and subsequently evaluated their performance with

82 respect to retaining water for a range of observed rainfall events. Yang et al. (2015)

83 experimented with a wide range of precipitation input to a similar model to explore the

84 performance under extreme conditions. Both studies showed a clearly decreasing

85 performance as events become larger.

86 The examples above show two important aspects in the evaluation of SCMs: 1)

87 Simulations with long time series of rainfall are necessary to determine how large a

88 proportion of the maximum efficiency of SCMs can actually be utilised in a more close-

89 to-real setting, and 2) it is necessary to calculate and present the efficiency of an SCM

90 for both the annual volume and for individual extreme events separately because

91 controlling of large volumes on an annual basis is not the same as provision of flood

92 protection.

93 To provide consistent reporting and avoid confusing communication about the

94 efficiency of SCMs, we suggest a method for reporting the efficiency of different

95 approaches based on 'rainfall domains'. Our method extends the Three Points Approach

96 (3PA) presented by Fratini et al. (2012), which defined three distinct decision domains, 
97 each governed by different professionals, affected by different stakeholders and

98 subjected to different values. We redefine the three domains from a hydrologic

99 perspective in terms of rainfall return periods relevant within the urban water cycle.

100 This allows calculating quantitative efficiencies for a given SCM in each domain with

101 respect to each flow, resulting in a matrix of metrics that together characterise the

102 performance of the given SCM comprehensively and clearly. Our proposed method

103 aims to facilitate better communication between different stakeholders about the

104 efficiency of different stormwater management strategies by answering questions like:

105 “under what circumstances may rainwater harvesting systems and other stormwater

106 control measures be expected to contribute efficiently to (A) rainwater resource

107 utilisation, (B) urban storm drainage pipe capacity and (C) pluvial flood mitigation?”.

108 The method is applied to three theoretical SCM strategies for the City of Copenhagen,

109 Denmark

\section{Methods and data}

111 All data analysis in this study is based on the assumption that a water balance can be

112 made at the municipal level. In our study we focused on the rainfall above a defined

113 municipal area and the engineered flows (stormwater runoff, supply of potable water

114 and wastewater flow directed to the wastewater treatment plant) as these together pose

115 the greatest cost to society (Kenway et al., 2011).

\section{Defining the domains of the 3PA}

117 In the original definition of The Three Points Approach (3PA) Fratini et al. (2012)

118 delineated three distinct domains in which decisions related to stormwater management

119 are made. They illustrated how the domains relate to distinct types of rainfall events that

120 occur with different magnitude and return period, cf. Figure 1. Adopting an urban 
121 drainage engineer viewpoint, they labelled these typical rain events decision points from

1221 to 3. Point 1 refers to the most important point for the urban drainage engineer, the

123 "what is my responsibility"-point, Point 2 refers to the second most important point, the

124 "what happens when the system capacity is exceeded"-point, and Point 3 refers to the

125 least important point, the "how could we do something alternative with the rainwater"-

126 point. However, in order of increasing magnitude of rain events, Fratini et al.'s domains

127 come in the sequence 3, 1, 2 and for quantitative evaluations, this numbering is less

128 intuitive. Hence, we renamed the Points A, B and C, where the point corresponding to

129 the smallest and most frequent events is named A and the point corresponding to the

130 largest and rarest events is named C (Figure 1). This modification to the 3PA is relevant

131 since SCMs perform differently for varying magnitudes of rain events. Furthermore, we

132 redefine the axes to reflect rainfall magnitude (vertical axis) and rainfall return period

133 (horizontal axis), allowing a quantification of the three points based on historical

134 rainfall time series.

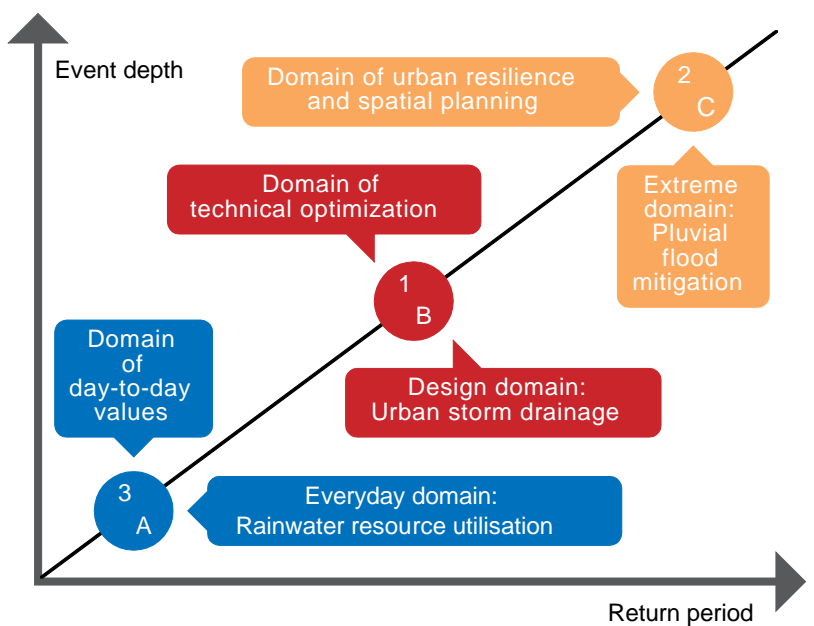

136 Figure 1. Conceptual definition of the 3PA domains. Fratini et al. (2012) defined the

137 3PA in domains 3, 1, 2 and we modified the labelling to A, B, and C in the order of 138 increasing return periods. 
140 Given these modifications we define the three rainfall domains in relation to the 3PA

141 points as:

142 Point A: Rainwater resource utilisation or the everyday domain. With respect to rainfall

143 this domain represents everything from dry weather to rainfall events that utilise the

144 capacity of the urban drainage systems without causing any direct wet weather

145 discharges to the environment. It acts as the design domain for a majority of

146 decentralized SCMs such as green roofs and soakaways.

147 Point B: Urban storm drainage pipe design domain. The rainfall in this domain is

148 described as events that traditional urban stormwater infrastructures are designed to

149 manage. The domain covers from rainfall events that cause controlled overflows to

150 surrounding water bodies and up until, but not including, rare rainfall events that are not

151 considered feasible to convey using traditional sewer systems. In other words, this

152 domain is capped at the point where floods from an engineering point of view are

153 considered to be acceptable. It is the most well defined and regulated of the three

154 domains. Performance requirements to sewers vary internationally, but everywhere in

155 the world people have expectations to how sewers are designed and operated, and in

156 many places, this will be regulated in detail by central guidelines and standards.

157 Point C: Pluvial flood mitigation, or the extreme domain. The rainfall in this domain

158 includes the rare events that cause floods in the urban environment, where the sewer

159 system no longer is sufficient to control the rainwater and where overland flows are

160 substantial or even dominating the drainage of the affected area. 
162 To assign a characteristic rain event to each domain of the 3PA we analysed historical

163 rainfall records considering different rain event durations (Jørgensen et al., 1998;

164 Madsen et al., 2009). For each rain series we identified events according to the

165 recommendations of Madsen et al. (2009) with a dry weather period between individual

166 events of the same length as the event duration definition. The obtained events were

167 ranked according to their maximum mean intensity over the event duration definition,

168 and the return periods for the events were calculated using the Median plotting position

169 (Rosbjerg, 1988):

$$
T_{m}=\left(T_{o b s}+0.4\right) /(m-0.3)
$$

171 where $T_{m}$ is the return period of an event with rank $m$ and $T_{o b s}$ is the total length of the

172 rain series. Event durations of 3, 12 and 24 hours were included in the analysis.

173 We chose a characteristic return period for each domain based on prevailing design

174 standards in Denmark. The Danish design criteria for rainwater harvesting and usage

175 were used to define Point $A$ as $T=0.2$ years (Teknologisk Institut, 2002). The

176 recommendation of the The Water Pollution Committee of The Society of Danish

177 Engineers to design of combined sewers for a return period of $\mathrm{T}=10$ years, which was

178 adopted by most municipalities in Denmark, was used to define Point B (Water

179 Pollution Committee of the Society of Danish Engineers, 2005). Point C principally

180 includes all events with $\mathrm{T}>10$ years, but in order to constrain the domain and quantify

181 the point explicitly we chose a return period of 100 years, which is a commonly used

182 design criterion.

183 Using these quantitative definitions of the three points, we assigned each rainfall event to its appropriate domain, summed up the rainfall volume in each domain and found the characteristic rainfall depths for each domain based on the historic rainfall records. 
187 We use the term efficiency to refer to a given SCM's capacity for managing and hence

188 altering flows in the urban water cycle. We define quantitative efficiencies $(E)$ as

189 metrics related to three major urban water flows (Figure 2): Rainfall, water supply and

190 flow to the wastewater treatment plant (assuming the SCM is implemented in an area

191 served by a combined sewer system).

192

193

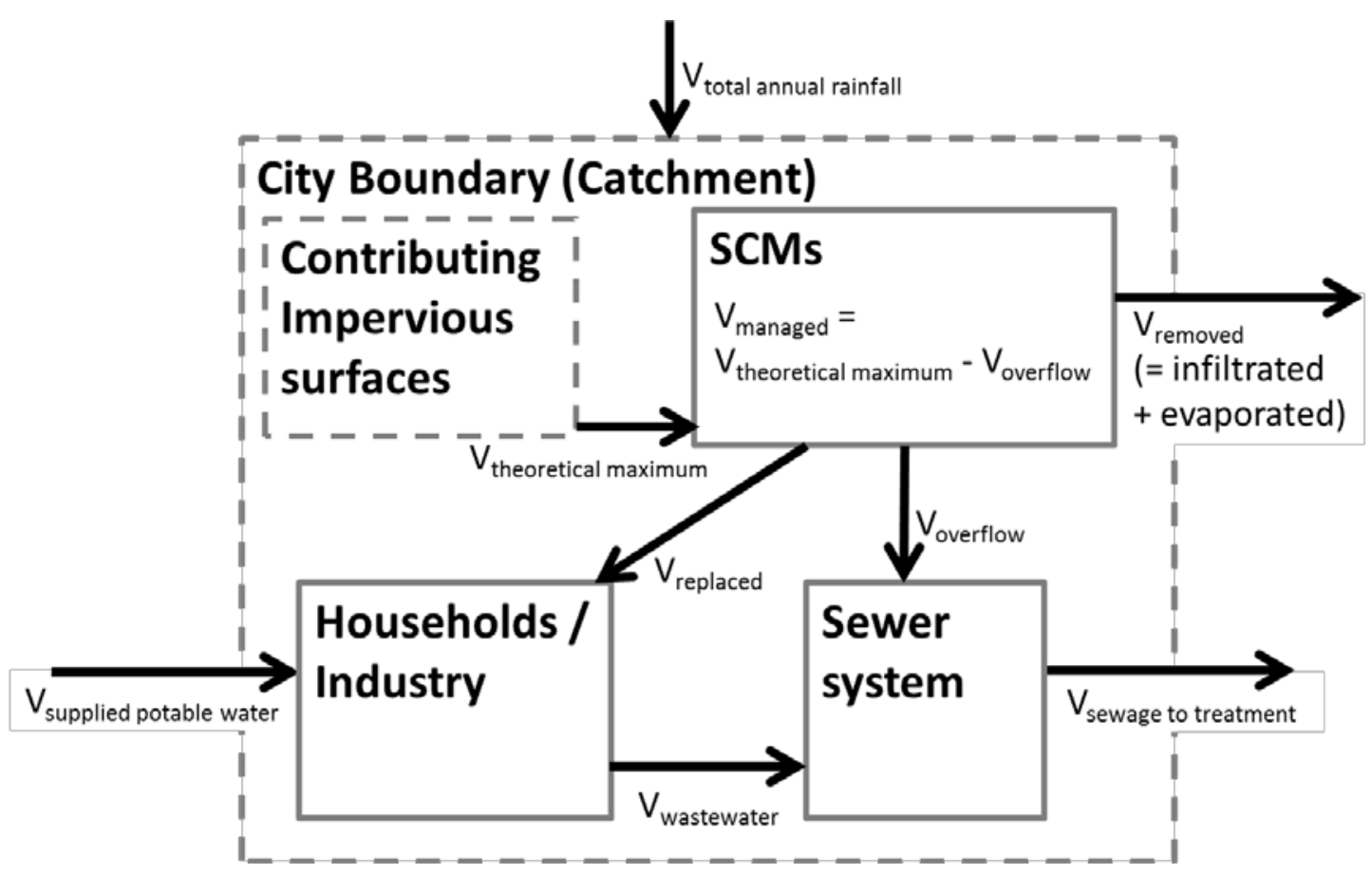

Figure 2. Major urban water flows relevant for SCM efficiency measures.

The efficiency related to volumetric Rainfall $\left(E_{r}\right)$ expresses how well an SCM is able to

197 exploit rainwater as a resource and is defined as:

$$
E_{r}=V_{\text {managed }} / V_{\text {total annual rainfall }}
$$

$199 V_{\text {total annual rainfall }}$ is the direct input flow to the city wide water balance and $E_{r}$ thus

200 depends directly on the spatial extent of the considered area. $E_{\text {rmax }}$ is the spatially 
201 independent efficiency metric expressing the ratio between managed volume ( $\left.V_{\text {managed }}\right)$ and the volume of rainfall received by the proposed SCM ( $\left.V_{\text {theoretical maximum }}\right)$ :

$$
E_{\text {rmax }}=V_{\text {managed }} / V_{\text {theoretical maximum }}
$$

204 The efficiency in reducing potable water demand $\left(E_{p w}\right)$ is a measure of how much an

205 SCM is able to decrease the potable water demand in the area of interest:

$$
E_{p w}=V_{\text {replaced }} / V_{\text {supplied potable water }}
$$

Finally, the efficiency in reducing the total wastewater production $\left(E_{w w}\right)$ describes the degree to which an SCM is able to alleviate the load on the treatment plant:

$$
E_{w w}=V_{\text {removed }} / V_{\text {sewage to treatment }}
$$

210 Together these four metrics of efficiency are used to quantify the potential impact of

211 SCMs on the major water flows in a city.

\section{$212 \quad 2.4 \quad$ Conditioning the SCM efficiencies on the 3PA domains}

213 The efficiency metrics defined above relate the individual volumes to key aggregated

214 annual water flows. In the following we outline how they were further conditioned on

215 rainfall domains using the 3PA. Hereby, the 3PA can be used to describe how well a

216 system designed for one rainfall domain functions when exposed to the defining rain

217 events of the other domains.

218 To calculate how much volume a structure designed for Point $i$ manages when exposed

219 to an event of Point $j$ we extend Eq. 2 to 5 as follows, illustrated with $E_{r}$ :

$$
E_{r}^{j \mid i}=f_{j} g_{i, j} E_{r}
$$

221 where $f_{j}$ is the fraction of the total annual rainfall volume that falls within Point $j . g_{i, j}$ is the theoretical fraction of the rainfall that the SCM designed for Point $i$ can manage when exposed to a Point $j$ event. The sum of $f_{j}$ 's over all three points will always be 1 . 
$224 g_{i, j}$ will be 1 for the design point and for any point below (with lower return periods) and

$225<1$ for any point above (with larger return periods); how much lower is determined 226 using historical rainfall records.

227 The $g_{i, j}$ is an engineering abstraction that reflects how an SCM will act under ideal

228 situations. In practice, the amount of rainwater an SCM can handle will depend on the

229 specific rain event depth but also on the volume of water already stored in the SCM at

230 the start of the rain event. Thus the $g_{i, j}$ calculated for each domain is a theoretical

231 maximum value that can only be achieved by over-sizing of the SCM (Water Pollution

232 Committee of the Society of Danish Engineers, 2005). Furthermore, the SCM capacity

233 expressed by $g_{i, j}$ will be reduced if the magnitude and return period of considered events

234 increase as the absolute amount of rainwater an SCM can handle is fixed.

\section{$235 \quad 2.5$ The case study}

236 The methodology outlined above was tested on the municipality of Copenhagen

237 considering three types of SCMs: two strategies for stormwater infiltration (cases 1 and

238 2) and one strategy for rainwater harvesting (case 3).

\section{2.5.1 Copenhagen municipality}

240 Copenhagen is almost fully urbanised, with major suburbs being part of surrounding

241 municipalities (see Table 1). The municipality has widespread combined sewer systems

242 resulting in a very large fraction of stormwater in the inflow to the wastewater treatment

243 plants under wet weather conditions (approximately 45\% on an annual basis). 
245 Table 1. Main attributes of the municipality of Copenhagen and its water balance. Water

246 balance attributes from year 2003 according to Hauger and Binning (2006).

\begin{tabular}{|c|c|c|}
\hline General attributes & & \\
\hline Catchment area $\left[\mathrm{km}^{2}\right]$ & $A$ & 89.9 \\
\hline Population $\left[10^{3}\right]$ & Pop & 548 \\
\hline Population density [persons $\mathrm{km}^{-2}$ ] & Pop $_{\text {density }}$ & 6096 \\
\hline Mean rainfall depth $\left[\mathrm{mm}\right.$ year $\left.{ }^{-1}\right]$ & $\operatorname{Pr}$ & 613 \\
\hline Water balance attributes & & \\
\hline Rainfall volume $\left[10^{6} \mathrm{~m}^{3}\right.$ year $\left.^{-1}\right]$ & $V_{\text {rainfall }}$ & 61.5 \\
\hline Supplied potable water $\left[10^{6} \mathrm{~m}^{3}\right.$ year $\left.{ }^{-1}\right]$ & $V_{\text {potable water }}$ & 32.8 \\
\hline Treated wastewater $\left[10^{6} \mathrm{~m}^{3}\right.$ year $\left.{ }^{-1}\right]$ & $\mathrm{V}_{\text {wastewater }}$ & 60.1 \\
\hline $\begin{array}{l}\text { Roof runoff to sewers }\left[\mathrm{m}^{6} 0^{6} . \mathrm{m}^{3} \text { year }^{-1}\right] \\
\left(V_{\text {Theoretical maximum }} \text { for Case } 3\right)\end{array}$ & $V_{\text {roof runoff }}$ & 6.1 \\
\hline $\begin{array}{l}\text { Flow from paved areas to sewers }\left[10^{6} \mathrm{~m}^{3} \text { year }^{-1}\right] \\
\left(V_{\text {Theoretical maximum }} \text { for Case } 1 \text { and } 2\right)\end{array}$ & $V_{\text {paved runoff }}$ & 23.0 \\
\hline
\end{tabular}

$248 \quad$ 2.5.2 Case data

249 A water balance used for planning purposes (Table 1) has been established previously

250 for Copenhagen (Hauger and Binning, 2006). The rainfall volumes presented in the

251 water balance are considered typical for the current conditions. Rainfall volumes in the

252 water balance (V's in Table 1) are based on only one year of data and are slightly (12\%)

253 wetter than time series averages ( $\mathrm{Pr}$ in Table 1). However, to maintain consistency it

254 was chosen to base efficiency metrics on the water balance.

255 We chose four different rain series of 20 years duration with 1-min resolution data,

256 which represent well the differences in mean annual precipitation within Denmark

257 (Table 2). 
259 Table 2. Overview of rain gauge data (see Jørgensen et al. 1998, for details about the 260 rainfall monitoring system).

\begin{tabular}{|c|c|c|c|c|}
\hline Station name & $\begin{array}{r}\text { Silkeborg } \\
\text { Vandværk }\end{array}$ & $\begin{array}{r}\text { Kolding } \\
\text { Renseanlæg }\end{array}$ & $\begin{array}{l}\text { Kongens } \\
\text { Enghave }\end{array}$ & $\begin{array}{r}\text { Måløv } \\
\text { Renseanlæg }\end{array}$ \\
\hline $\begin{array}{l}\text { Station } \\
\text { number }\end{array}$ & 5192 & 5251 & 5765 & 5600 \\
\hline Coordinates & $\begin{array}{r}56^{\circ} 09^{\prime} 44.0^{\prime \prime} \mathrm{N} \\
9^{\circ} 33^{\prime} 36.3^{\prime \prime} \mathrm{E}\end{array}$ & $\begin{array}{r}55^{\circ} 29^{\prime} 21.5^{\prime \prime} \mathrm{N} \\
9^{\circ} 29^{\prime} 14.2^{\prime \prime E}\end{array}$ & $\begin{array}{c}55^{\circ} 38^{\prime} 44.5^{\prime \prime} \mathrm{N} \\
12^{\circ} 32^{\prime} 02.9^{\prime \prime} \mathrm{E}\end{array}$ & $\begin{array}{c}55^{\circ} 45^{\prime} 40.2^{\prime \prime} \mathrm{N} \\
12^{\circ} 19^{\prime} 08.7^{\prime \prime} \mathrm{E}\end{array}$ \\
\hline Record period & 1979-1998 & 1979-1998 & 1979-1998 & 1979--1998 \\
\hline $\begin{array}{l}\text { Corrected } \\
\text { Length [years] }\end{array}$ & 17.10 & 17.30 & 17.25 & 17.13 \\
\hline $\begin{array}{l}\text { Mean Annual } \\
\text { Precipitation } \\
\text { [mm] }\end{array}$ & 720 & 765 & 615 & 610 \\
\hline
\end{tabular}

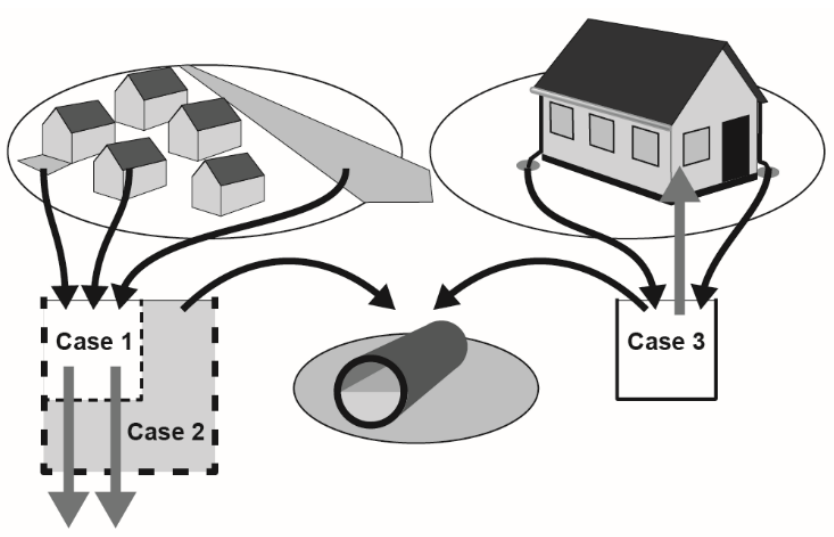

264 Figure 3. Illustration of the investigated SCMs. In Case 1 and 2 we consider infiltration

265 of stormwater via soakaways with two different dimensions, and in Case 3 we consider

266 a rainwater harvesting tank with subsequent indoor use. All three SCMs include

267 overflow to a combined sewer system. 
269 Case 1 (Figure 3) considers all impermeable areas of the city as catchment area. It

270 considers soakaways dimensioned according to the Danish design guidelines for

271 rainwater harvesting systems (Mikkelsen et al., 1999; Teknologisk Institut, 2002),

272 which corresponds to a design for Point A, i.e. a design for rainfall events with return

273 periods of up to 0.2 year.

274 Case 2 (Figure 3) is designed with the same catchment area as Case 1 but considering

275 soakaways dimensioned according to the design guidelines of sewer systems, which

276 corresponds to a design for Point B, i.e. a design for rainfall events with return periods

277 of up to 10 years.

278 The stormwater infiltrated in cases 1 and 2 cannot be directly used to replace potable

279 water and will therefore by definition gain an $E_{p w}$ value of zero (the importance of

280 increasing groundwater recharge is considered negligible).

281 Case 3 (Figure 3) considers rainwater harvesting tanks, where the water is used for

282 flushing toilets. The use of the collected water entails more restrictions on the design

283 than soakaways. We follow the Danish design guidelines (Mikkelsen et al., 1999;

284 Teknologisk Institut, 2002) that allow water to be collected only from roofs. To avoid

285 too long storage periods the system must be flushed regularly, hence a design for Point

286 A is required (Teknologisk Institut, 2002). In Case 3, the SCM has the added value of

287 replacing potable water, and thus has the potential for reducing potable water demand

288 expressed in the metric $E_{p w}$.

289 In all cases, we assume that when the capacity of the SCMs is exceeded it overflows to

290 the sewer system, which is designed for a return period of 10 years (Point B). For events

291 exceeding Point B SCMs overflow to the surface. 


\section{$292 \quad 3 \quad$ Results}

\section{$293 \quad 3.1 \quad$ Event depths and accumulated rainfall volumes for each 3PA domain}

294 The analysis of the historical rain records shows that the depth of events in the everyday

295 domain (Point A) is approximately $20 \mathrm{~mm}$ (Figure 44a). For Point B and C the depths

296 are 70 and $110 \mathrm{~mm}$ respectively. However, the main part of the accumulated annual

297 rainfall falls within the everyday domain (75\%) and the design domain (24\%) (Figure

298 44b). An SCM designed for a return period of 0.2 years will thus manage $75 \%$ of the

299 annual rainfall volume and a design for a return period of 10 years will manage

300 approximately 99\% of the annual rainfall volume (points A and B aggregated). This

301 leaves virtually no volume in the extreme domain in terms of annual rainfall volume.

302 The difference between aggregating rain in 3-hour and 24-hour events only changes the

303 volume falling in the everyday domain (Point A) from approximately $80 \%$ to $70 \%$ and

304 in the design domain (Point B) from approximately 20\% to 30\%, with the longer event

305 aggregation allocating more water to the design domain (Point B). In contrast, the

306 choice of event duration has negligible influence on the accumulated volume falling in

307 the extreme domain (Point C) as this is always very small. 

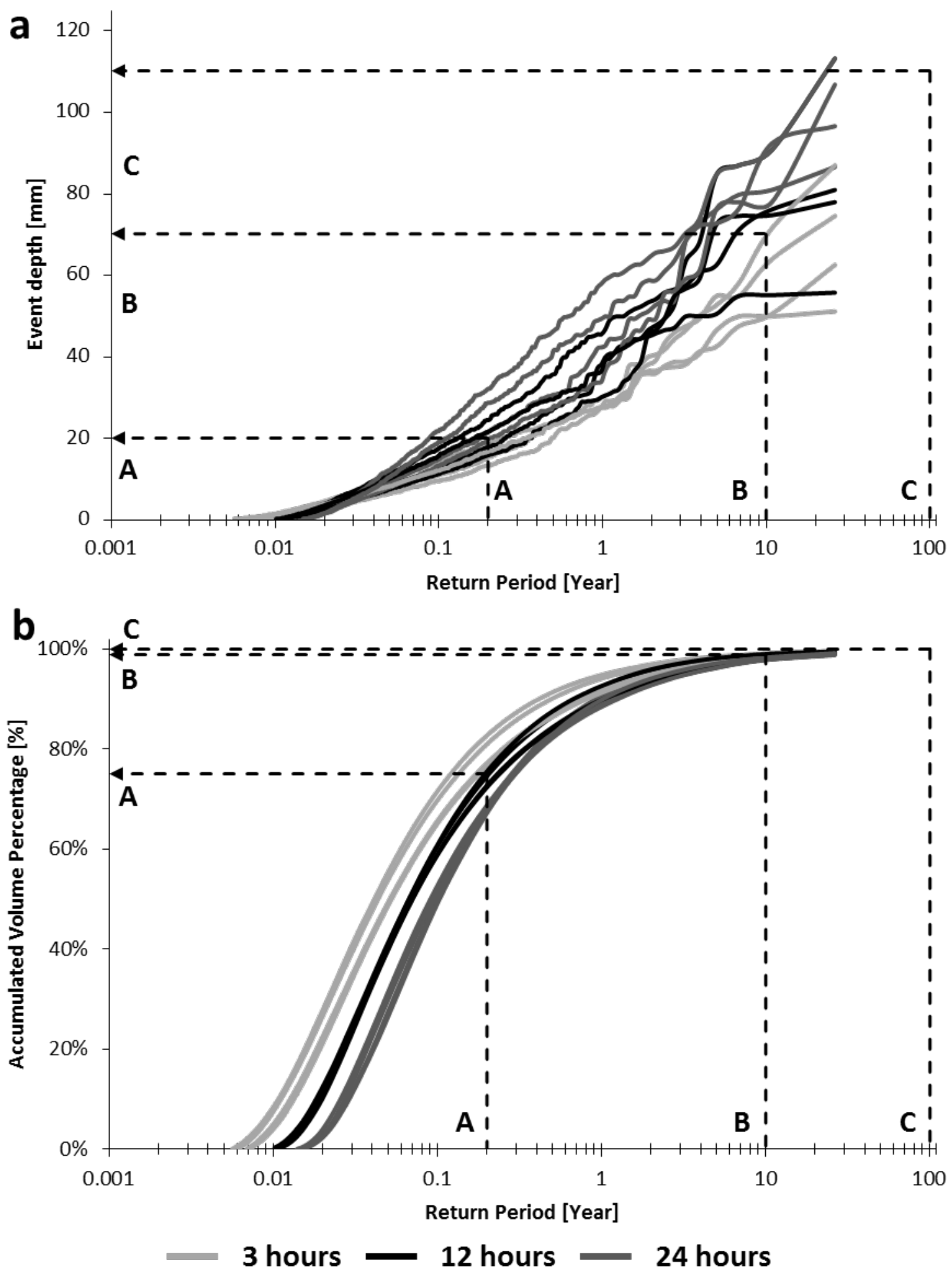

309 Figure 4. Usage of precipitation data to quantify the 3PA. a: Event depths ranked

310 according to return period and marking of which event depths that constitute the

311 different points in the 3PA. b: Volumetric percentages of total rainfall that falls within 
312 the domains of the 3PA. Three different event definitions were included (3, 12 and 24

313 hour extremes), each calculated for four different rainfall series (from different parts of

314 Denmark), resulting in 12 curves in total. The dotted vertical lines at return periods of

3150.2 years and 10 years represent Point $A$ and $B$ of the 3PA (Figure 1). Point $C$ is

316 represented by average extrapolation of trends until 100 years.

318 Based on these findings, we define the three domains in quantitative terms for the

319 Danish context as follows:

- Point A - The Everyday Domain: The defining event within this domain has a

In the supplementary material these results are depicted directly on the 3PA graph purposes.

\subsection{Theoretical efficiency distribution}

334 Eq. 5 is used to calculate what happens when an SCM designed for one point is exposed to rainfall from other points. When a soakaway designed to store $20 \mathrm{~mm}$ of rain (Point 
336 A) is exposed to a Point B event, i.e. $70 \mathrm{~mm}$ of rain, it will manage $20 \mathrm{~mm}$ (29\%), and

$33750 \mathrm{~mm}$ (71\%) will overflow from the structure. The inter-event time has little influence

338 on the annual volumes defining the different domains (Figure 4b). The relationship

339 between the points in the 3PA expressed in the $g_{i, j}$ fraction, has been calculated using

340 the typical Danish rainfall events defined above (Table 3).

341 
342 Table 3. Fraction of rainfall event depth that can be managed by a structure designed for

343 a specific point in the domains A, B and C dependent on the rainfall input domain.

\begin{tabular}{ll|lrr} 
& $g_{i, j}$ & $\begin{array}{l}\boldsymbol{j}=\text { event type } \\
\text { Point A - } \\
\text { Everyday }\end{array}$ & $\begin{array}{l}\text { Point B - } \\
\text { Design }\end{array}$ & \multicolumn{1}{l}{$\begin{array}{l}\text { Point C - } \\
\text { Extreme }\end{array}$} \\
\hline $\begin{array}{l}\boldsymbol{i}=\text { design } \\
\text { criteria }\end{array}$ & $\begin{array}{l}\text { Point A - } \\
\text { Everyday } \\
\text { Point B - } \\
\text { Design } \\
\text { Point C - } \\
\text { Extreme }\end{array}$ & 1.00 & 0.29 & 0.18 \\
& 1.00 & 1.00 & 0.64 \\
& 1.00 & 1.00 & 1.00
\end{tabular}

\section{$344 \quad 3.3 \quad 3 P A$ efficiencies}

345 The SCM in Case 1 (soakaways designed for Point A) manages 31\% of the annual

346 rainfall $\left(E_{r}\right)$ corresponding to 19 mill. $\mathrm{m}^{3}$ year $^{-1}$ (Table 4). The results reflect that the

347 structure is able to control $83 \%$ of the total water volume entering the structure $\left(E_{r \max }\right)$.

348 Distributed in rainfall domains, the SCM manages $100 \%$ of the annual rainfall in Point

349 A, 29\% of the annual rainfall in Point B and 18\% of the annual volume in Point C.

The SCM in Case 2 (soakaways designed for Point B) manages slightly more rainfall on

351 annual basis with 37\% (Table 4). This corresponds to almost 100\% (99.6\% actually) of

352 the theoretical maximum volume $\left(E_{r \operatorname{rmax}}\right)$, distributed with $100 \%$ for Point $\mathrm{A}$ and B rain 353 events, and 64\% for Point C events.

354 The efficiency in reducing combined sewage $\left(E_{w w}\right)$ is notable for both Cases 1 and 2, with reduction percentages of 31-38\%. Since infiltration does not affect the potable water demand, $E_{p w}$ is zero for Cases 1 and 2.

357 The SCM in case 3 (rainwater harvesting for use in households) manages much less

358 water than in Cases 1 and 2, with $E_{r}$ of 9\% (Table 4). The relative rainfall control

359 efficiency $\left(E_{r \max }\right)$ is equal to that in Case 1 with $83 \%$, but note that this may be

360 misleading since in our example the relevant catchment areas in case 3 comprise only 
361 roofs, and thus only 5.7 mill. $\mathrm{m}^{3}$ year $^{-1}$, respectively, are managed in Case 3. Although

362 the relative rainfall control $\left(E_{\text {rmax }}\right)$ and the absolute volume managed in Case 3 are

363 significantly smaller than in cases 1 and 2, the 9.4\% reductions in combined sewage

$364\left(E_{w w}\right)$ are still notable from the point of view of a wastewater treatment plant manager.

365 Since the harvested rainwater replaces potable water, there is also a marked reduction in 366 potable water demand $\left(E_{p w}=17 \%\right)$. 
Table 4. Efficiency metrics for Cases 1 to 3 calculated using Eq. 2-6, given as percentages.

\begin{tabular}{|c|c|c|c|c|c|c|c|c|c|c|c|c|}
\hline \multirow{2}{*}{$\begin{array}{l}\text { Copenhagen } \\
\text { 3PA rainfall domains (points) } \\
\text { Efficiencies [\%] }\end{array}$} & \multicolumn{4}{|c|}{$\begin{array}{c}\text { Case } 1 \\
\text { (soakaway designed for Point A) }\end{array}$} & \multicolumn{4}{|c|}{$\begin{array}{c}\text { Case } 2 \\
\text { (soakaway designed for Point B) }\end{array}$} & \multicolumn{4}{|c|}{$\begin{array}{c}\text { Case } 3 \\
\text { (Harvesting and use designed } \\
\text { for Point A) } \\
\end{array}$} \\
\hline & $\mathbf{A}$ & $\mathbf{B}$ & C & Total & $\mathbf{A}$ & $\mathbf{B}$ & $\mathbf{C}$ & Total & $\mathbf{A}$ & $\mathbf{B}$ & $\mathbf{C}$ & Total \\
\hline Volumetric rainfall control $\left(E_{r}\right)$ & 28 & 2.6 & 0.0068 & 31 & 28 & 9.0 & 0.24 & 37 & 8.4 & 0.77 & 0.020 & 9.2 \\
\hline Relative rainfall control $\left(E_{r \max }\right)$ & 100 & 29 & 10 & 83 & 100 & 100 & 64 & 100 & 100 & 29 & 18 & 83 \\
\hline Potable water demand reduction $\left(E_{p w}\right)$ & 0.0 & 0.0 & 0.0 & 0.0 & 0.0 & 0.0 & 0.0 & 0.0 & 16 & 1.4 & 0.038 & 17 \\
\hline Wastewater production reduction $\left(E_{w w}\right)$ & 29 & 2.6 & 0.070 & 31 & 29 & 9.2 & 0.24 & 38 & 8.6 & 0.79 & 0.021 & 9.4 \\
\hline Volume managed [mill. $\mathbf{m}^{3}$ year $^{-1}$ ] & 17 & 1.6 & 0.042 & 19 & 17 & 5.5 & 0.15 & 23 & 5.2 & 0.47 & 0.013 & 5.7 \\
\hline
\end{tabular}


370 The efficiency scores attained in the case study SCMs illustrate the conflict of goals

371 described in the introduction between managing large volumes of water over time and

372 managing single extreme events. Whether domain A, B, or C is the cause of concern is

373 case specific and will depend on the context of the catchment in question (Lerer et al.,

374 2015). For example, in some areas water conservation and reduction in potable water

375 use is a main concern and driver for SCMs (Campisano and Modica, 2015; Londra et

376 al., 2015). In other areas, the main concern may be limiting combined sewer overflows

377 (Petrucci et al., 2012; Stovin et al., 2013) or to conserve the pre-development catchment

378 water balance (Henrichs et al., 2016) and the river flow regime (Fletcher et al., 2013).

379 Finally, other places mainly respond to increasing flood risks (Zhou et al., 2013).

380 Common for the cases is that inclusion of SCMs in the urban water management system

381 will influence the full water cycle and not only the component of main concern. This is

382 where our proposed efficiency metrics and the 3PA may help decision makers to

383 identify additional benefits or unexpected caveats of potential SCM setups.

384 From a volumetric point of view, all the SCMs analysed manage more than $83 \%$ of the annual rainfall in their catchment area, as expressed by the relative rainfall efficiency, $E_{\text {rmax }}$. From a resource perspective this is very satisfactory as the SCMs considerably ease the load on the wastewater treatment plant (assuming the catchments otherwise drain to a combined sewers system), and in Case 3 the SCM also considerably reduces

389 potable water demand. In other words, this high overall efficiency of the SCMs, corresponding to a very high efficiency in the everyday domain, reflects that these SCMs perform well in terms of rainwater resource utilization.

392 However, the efficiency metrics scored in the two other 3PA domains, the design

393 domain and the extreme domain, reveal that the SCMs we analysed are less promising 
394 in terms of flood risk mitigation. In Case 1 and 3 the SCMs manage $29 \%$ of the rainfall

395 volume for Point B events and 18\% for Point C events, on an annual basis. These

396 numbers reflect an idealized situation where the entire storage capacity of the SCM is

397 available at the onset of the rain event. In reality, the storage will rarely be fully

398 available and the performance will be accordingly less efficient. An SCM dimensioned

399 to hold $20 \mathrm{~mm}$ of rainfall will not always be empty at the onset of a rain event and can

400 therefore not always manage all $20 \mathrm{~mm}$. However, long term simulations indicate that

401 this has little influence on the annual water balance (Locatelli et al., 2015) and the

402 simplification is justified for citywide planning purposes. Efficiencies calculated using

403 the 3PA domains demonstrate that the same SCM performs differently within the

404 different rainfall domains. This is not necessarily evident to all professionals working

405 with city infrastructure, yet it is crucial to understand when making decisions on

406 investments in stormwater management systems.

407 Case 2 illustrates how the volume of soakaways needed to meet the design requirements

408 of Point B is approximately three times larger than the volume needed to meet the

409 requirements for Point A (Case 1). Yet, the annual volume managed by the larger SCM

410 increases only $21 \%$ in our case (from 19 to 23 mill. $\mathrm{m}^{3}$ year ${ }^{-1}$ ).

411 When designing SCMs to reduce flood risk it is important to focus on the domain of 412 extremes (Point C). One possible solution to improve the performance of SCMs in case

413 of extreme rainfall events is to build in a mechanism that ensures all possible storage

414 space is available at the onset of the rain event, e.g. based on a real-time control scheme

415 (Han, 2013). This will give a higher efficiency for Point C (and potentially also for

416 Point B), at the expense of the efficiency of Point A. In other words, keeping volume

417 available for rare events will reduce the volume managed annually. Our approach

418 facilitates a clear message to the non-technical decision maker: SCMs that exploit the 
419 full potential for managing the annual water balance (illustrated by the efficiency metrics of the everyday domain) will not perform optimally during all extreme events

421 (illustrated by the efficiency metrics of the extreme domain). As such, the design of

422 SCMs should explicitly take into account and balance the perceptions and findings in

423 relation to the main problems in the analysed catchment.

424 While it may remain challenging to interpret the efficiencies for rainfall control $\left(E_{r}\right.$ and

$\left.425 E_{r \max }\right)$, the efficiencies for reducing potable water demand and wastewater production

426 have rather straight forward benefits. Reduction in potable water demand is a positive

427 outcome in terms of environmental protection of the water resource and reduced burden

428 on production and distribution of potable water. Reduction in wastewater production

429 saves operational costs at the wastewater treatment plant in case of combined sewer

430 systems, and may even in some cases delay or eliminate a need for expanding the

431 wastewater treatment plant. In catchments with frequent overflows from a combined

432 sewer system, the environmental benefit of reduced wastewater production may also be

433 significant.

434 Note that many SCMs offer additional benefits not considered here. For example, SCMs

435 that add blue-green elements like swales or stormwater ponds may increase

436 biodiversity, aesthetical value and recreational value (Zhou et al., 2013). Holistic

437 assessments of SCMs should go beyond our proposed metrics and include such

438 additional benefits as well.

\section{$4395 \quad$ Conclusions}

440 Our method facilitates the analysis of Stormwater Control Measures (SCMs) impact on

441 the urban water balance in three rainfall domains of the Three Points Approach (3PA):

442 A) the everyday domain, B) the urban stormwater pipe design domain, and C) the

443 pluvial flood mitigation, or extreme, domain. 
444 The method is useful to assess and communicate:

445

446

447

448

449

450

451

452

453

454

455

456

457

458

459

460

461

462

- which rainfall domain a given SCM is most suitable for,

- how much rain an SCM can manage when designed and re-designed for different design criteria, and

- how an SCM responds when its design criterion is exceeded.

The domains of the 3PA have been quantified for Danish conditions in terms of return periods and rain depth. Based on this quantification, it was found that SCMs such as rainwater harvesting or soakaways, designed to manage $100 \%$ of the rainfall from the everyday domain, will manage only $29 \%$ of the rainfall from the design domain and just $18 \%$ of rainfall from the extreme domain. This indicates that SCMs are not very effective means to reduce the risk of flooding. On the other hand, the efficiencies show that by harvesting only a minor fraction of the total rainfall (9\%), the annual volumes conveyed to wastewater treatment can be reduced with $12 \%$ and the potable water demand can be reduced by up to $19 \%$. This suggests that large scale implementation of SCMs may have substantial benefits in relation to resource utilization.

We believe that the simplicity of our method and the transparency of the results make it well suited to communicate the evaluation criteria used by engineers to other stakeholders involved in the decision process for SCMs such as urban planners and politicians.

\section{References}

464 Armson, D., Stringer, P., Ennos, A.R. (2013). The effect of street trees and amenity grass on 465 urban surface water runoff in Manchester, UK. Urban Forestry \& Urban Greening, 12(3), 466 pp. 282-286. doi: 10.1016/j.ufug.2013.04.001. 
Arnbjerg-Nielsen, K., Willems, P., Olsson, J., Beecham, S., Pathirana. A., Gregersen, I.B., Madsen, H., Nguyen, V-T-V. (2013). Impacts of climate change on rainfall extremes and urban drainage systems: a review. Water Science and Technology, 68( 1), pp. 16-28. doi: 10.2166/wst.2013.251.

Campisano, A. and Modica, C. (2015). Selecting time scale resolution to evaluate water saving and retention potential of rainwater harvesting tanks. Journal of Hydroinformatics, 17, pp. 331-346. doi:10.2166/hydro.2015.022.

Chocat, B., Ashley, R., Marsalek, J., Matos, M. R., Rauch, W., Schilling, W. \& Urbonas, B. (2007). Toward the sustainable management of urban storm-water. Indoor and built environment, 16(3), pp. 273-285. doi: 10.1177/1420326X07078854.

Committee on Reducing Stormwater Discharge Contributions to Water Pollution (2009). Urban Stormwater Management in the United States. National Academies Press, Washington DC. ISBN: 9780309125390.

Fletcher, T.D., Andrieu, H. and Hamel, P. (2013). Understanding, management and modelling of urban hydrology and its consequences for receiving waters: A state of the art. Advances in Water Resources, 51, pp. 261-279. doi:10.1016/j.advwatres.2012.09.001.

Fletcher, T.D., Shuster, W., Hunt, W.F., Ashley, R., Butler, D., Arthur, S., Trowsdale, S., Barraud, S., Semadeni-Davies, A., Bertrand-Krajewski, J.-L., Mikkelsen, P.S., Rivard, G., Uhl, M., Dagenais, D. and Viklander, M. (2015). SUDS, LID, BMPs, WSUD and more The evolution and application of terminology surrounding urban drainage. Urban Water Journal, 12(7), pp. 525-542. doi:10.1080/1573062x.2014.916314. for urban flood risk management: A tool to support climate change adaptation through transdisciplinarity and multifunctionality. Urban Water Journal, 9(5) pp. 317. doi: 
Han, M. (2013) Progress of multipurpose and proactive rainwater management in Korea.

Hauger, M.B. and Binning, P.J. (2006). Integrated management of water and wastewater in Copenhagen: Mapping of present resources and use and existing cleaning technologies for water and wastewater [Integreret håndtering af vand og spildevand i København:

Henrichs, M., Langner, J. and Uhl, M. (2016). Development of a simplified urban water balance model (WABILA). Water Science and Technology, doi:10.2166/wst.2016.020.

Jørgensen, H.K., Rosenørn, S., Madsen, H. and Mikkelsen, P.S. (1998). Quality control of rain data used for urban runoff systems. Water Science and Technology 37(11) pp. 113-120. doi:

Kenway, S., Gregory, A., and McMahon, J. (2011). Urban Water Mass Balance Analysis. Journal of Industrial Ecology, 15(5), 693-706. doi:10.1111/j.1530-9290.2011.00357.x.

Lerer, S.M., Arnbjerg-Nielsen, K., and Mikkelsen, P.S. (2015). A Mapping of Tools for Informing Water Sensitive Urban Design Planning Decisions—Questions, Aspects and Context Sensitivity. Water, 7(3), pp. 993-1012. doi:10.3390/w7030993. the impact of retention-detention units on sewer surcharge and peak and annual runoff

513 reduction. Water Science and Technology, 71, pp. 898-903. doi:10.2166/wst.2015.044. (2014). Modelling of green roof hydrological performance for urban drainage applications. Journal of Hydrology, 519(Part D), pp. 3237-3248. 10.1016/j.jhydrol.2014.10.030. 
516 Londra, P.A., Theocharis, A.T., Baltas, E. and Tsihrintzis, V.A. (2015). Optimal Sizing of 517 Rainwater Harvesting Tanks for Domestic Use in Greece. Water Resources Management, 518 29, pp. 4357-4377. doi:10.1007/s11269-015-1064-1.

519 Madsen, H., Arnbjerg-Nielsen, K. and Mikkelsen, P.S. (2009). Update of regional intensity520 duration-frequency curves in Denmark: Tendency towards increased storm intensities. 521 Atmospheric Research 92(3), pp. 343-349. doi: 10.1016/j.atmosres.2009.01.013.

522 Mikkelsen, P.S., Adeler, O.F., Albrechtsen, H.-J. and Henze, M. (1999). Collected rainfall as a 523 water source in Danish households - What is the potential and what are the costs? Water 524 Science and Technology, 39(5) pp. 49-56. doi: 10.1016/S0273-1223(99)00086-4.

525 Petrucci, G., Deroubaix, J.-F., de Gouvello, B., Deutsch, J.-C., Bompard, P. and Tassin, B. 526 (2012). Rainwater harvesting to control stormwater runoff in suburban areas. An 527 experimental case-study. Urban Water Journal, 9, pp. 45-55. doi: $528 \quad 10.1080 / 1573062 X .2011 .633610$.

529 Rosbjerg, D. (1988). Defence of the median plotting position. Progress Report - Institute of 530 Hydrodynamics and Hydraulic Engineering, Technical University of Denmark, (66), 17-28.

531 Schuster, W.D., Bonta, J., Thurston, H., Warnemuende, E. and Smith, D.R. (2005) Impacts of 532 impervious surface on watershed hydrology: a review. Urban Water Journal, 2(4). doi: 10.1080/15730620500386529.

534 Stovin, V.R., Moore, S.L., Wall, M. and Ashley, R.M. (2013) The potential to retrofit 535 sustainable drainage systems to address combined sewer overflow discharges in the Thames 536 Tideway catchment. Water and Environment Journal, 27(2), pp. 216-228. doi: 10.1111/j.1747-6593.2012.00353.x.

538 Teknologisk Institut (2002) Use of rainwater for toilet flushing and laundry in households [Brug 539 af regnvand til wc-skyl og vaskemaskiner i boliger], Rørcenter-anvisning 003, 2. udgave. In $540 \quad$ Danish. 
541 Water Pollution Committee of the Society of Danish Engineers (2005) Script 27 - Practical

542 function of urban drainage systems during rain [SKRIFT 27 - Funktionspraksis for

543 afløbssystemer under regn]. In Danish

544 Yang, W.-Y., Li, D., Sun, T., and Ni, G.-H. (2015). Saturation-excess and infiltration-excess

545 runoff on green roofs. Ecological Engineering, 74, 327-336.

546 doi:10.1016/j.ecoleng.2014.10.023

547 Zhou, Q., Panduro, T.E., Thorsen, B.J. and Arnbjerg-Nielsen, K. (2013). Adaption to Extreme

548 Rainfall with Open Urban Drainage System: An Integrated Hydrological Cost-Benefit

549 Analysis. Environmental Management, 51(3), 586-601. doi: 10.1007/s00267-012-0010-8. 